Syntax Literate: Jurnal Ilmiah Indonesia p-ISSN: 2541-0849

e-ISSN: 2548-1398

Vol. 7, No. 1, Januari 2022

\title{
A PROGNOSTIC MODEL BASED ON XRCC1 GENE POLYMORPHISMS AND CLINICOPATHOLOGICAL FACTORS TO PREDICT ONE-YEAR SURVIVAL OF ADVANCED EPITHELIAL OVARIAN CANCER PATIENTS
}

\author{
Chamim S. Singoprawiro, Iswari Setianingsih, Bambang Sutrisna, Nuryati C. \\ Siregar, Andrijono \\ Department of Obstetrics and Gynecology, Fatmawati General Hospital, Jakarta; \\ Eijkman Molecular Biology Institute, Jakarta; University of Indonesia, Depok \\ Email: dr_chamim@yahoo.com, Iswari_setianingsih@yahoo.com, \\ bambangsutrisna@yahoo.com, anisiregar01@yahoo.com, andrijono@gmail.com
}

\section{Abstract}

Prognosis of advanced stage epithelial ovarian cancer (EOC) patients remains poor due to recurrence and disease progression after surgery and chemotherapy. Polymorphism in the genes involved in DNA repair, i.e. X-ray repair cross complementing protein-1 (XRCC1) and XRCC3 could alter function, diminish repair kinetics and may play a role in tumor resistance to therapy. This study was aimed to predict the prognosis of advanced stage EOC patients based on the polymorphism of XRCC1 and XRCC3 genes and the clinicopathology. This was an ambispective cohort study in EOC patients treated in Fatmawati General Central Hospital and its network hospitals in Jakarta between 2011 and 2016. Demographic data and clinicopathology was obtained from the medical record. Polymorphisms of $\mathrm{XRCC} 1$ and XRCC3 genes were detected by using polymerase chain reactionrestriction fragment length polymorphism (PCR-RFLP) method. Survival analyses were performed using the Kaplan-Meier curve and Cox proportional hazard test. Multivariate analyses were performed to obtain prediction model for 1-year survival. Scoring system was developed and tested using the receiver operating characteristic (ROC) curve analyses. A total of 129 eligible cases were included. Patients' mean age was 49.6 years. Most patients (93.8\%) were having stage III disease. Mortality at 1-year was associated with three independent variables, i.e. histopathology subtype, residual tumor $>1 \mathrm{~cm}$, and XRCC1 gene Arg399Gln polymorphisms (Arg/Gln or Gln/Gln alleles). These prediction models gave $85.3 \%$ accuracy by ROC curve analysis and $82.7 \%$ posttest probability. Prognosis of advanced stage EOC patients can be predicted from several clinicopathological factors and XRCC1 gene polymorphisms. Validation study is needed to confirm these findings.

Keywords: advanced stage epithelial ovarian cancer; recurrence; one-year mortality; XRCC1; XRCC3 genes polymorphisms.

Received: 2021-12-20; Accepted: 2022-01-05; Published: 2022-01-15

$\begin{array}{ll}\text { How to cite: } & \text { Singoprawiro. C.S., Iswari Setianingsih, Bambang Sutrisna \& Nuryati C. Siregar, Andrijono (2022) A } \\ & \text { Prognostic Model Based on XRCC1 Gene Polymorphisms and Clinicopathological Factors to Predict One- } \\ & \text { Year Survival of Advanced Epithelial Ovarian Cancer Patients. Syntax Literate: Jurnal Ilmiah Indonesia, } \\ & 7(1) . \text { http://dx.doi.org/10.36418/ Syntax-Literate.v7i1.5653 } \\ \text { E-ISSN: } & \text { 2548-1398 } \\ \text { Published by: } & \text { Ridwan Institute }\end{array}$


Chamim S. Singoprawiro, Iswari Setianingsih, Bambang Sutrisna, Nuryati C. Siregar, Andrijono

\section{Introduction}

Epithelial ovarian cancer (EOC) comprises $80-90 \%$ of all ovarian cancers (Berek \& Hacker, 2010), (Novak, 2007) It is the second most common gynecological cancer after cervical cancer with an estiated new cases of 22,280 in 2012 (Jhamb \& Lambrou, 2010), (Jinawath \& Shih, 2010). The incidence of EOC in Indonesia is not clearly known; a small study in Cipto mangunkusumo, Hospital, Jakarta found 48 out of 50 (96\%) malignant ovarian tumors were EOCs (Winarto, Laihad, \& Nuranna, 2014). Despite new advances in tretment, prognosis of ovarian cancer remains dismal. Recurrence rate in the first 3-year after treatment is about 60\% (Novak, 2007), (Jhamb \& Lambrou, 2010). Data from Cipto Mangunkusumo Hospital, Jakarta as a national referral hospital found $51 \%$ of EOC came in stage III-IV with a 5-year survival rates of $31 \%$ and $11.7 \%$, respectively (Aziz, 2009). Recurrence may worsen prognosis since most of cases tend to be resistant to chemotherapy agents. Tumor resistance to platinum-based therapy may be caused by successful DNA repair and tolerance to chemoterapy induced DNA damage (Almeida, Duarte, Farmer, Steward, \& Jones, 2008).

Several studies has found the relationship between DNA repair genes polymorphism and cancer susceptibility (Zhao, Deng, Wang, Wang, \& Liu, 2012), (Goode, Ulrich, \& Potter, 2002) Polymorphisms of the repair genes may also play a role in patient's survival after treatment (Bewick, Conlon, \& Lafrenie, 2006) In ovarian cancer, the XRCC1 $194 \mathrm{Trp} / \mathrm{Trp}$ and $399 \mathrm{Gln} / \mathrm{Gln}$ polymorphism was reported to have significant association with the patients' survival after chemotherapy (Miao, Zhang, Tang, Wang, \& Kai, 2012). Other study found that XRCC1 Arg399GIn and XRCC4 Thr241Met polymorphisms has shorter survival than the normal alleles (Cheng, Xue, Li, $\& \mathrm{Li}, 2012)$.

Polimorfisme gen XRCC1 yang mengakibatkan perubahan asam amino terjadi pada 3 lokasi dengan kekerapan alel (allele frequency) berkisar dari 8\% sampai 25\%, yaitu kodon 194 ekson 6 (Arg>Trp), kodon 280 ekson 9 (Arg>His), dan kodon 399 ekson 10 (Arg>Gln) (Shen, Jones, \& Mohrenweiser, 1998).

This study was aimed to develop a prediction model on 1-year survival in patients with advanced EOC at 1-year after therapy based on the XRCC1 and XRCC3 genes polymorphisms and clinicopathological factors.

\section{Research Methods}

1. Study Design And Subjects

This was an ambispective cohort study in EOC patients treated in Fatmawati General Central Hospital and network hospitals in Jakarta between 2011 and 2016. Subjects were stage III and IV EOC patients who underwent debulking surgery followed by chemotherapy. Demographic data and clinicopathology characteristics was obtained from the medical record. 
A Prognostic Model Based on XRCC1 Gene Polymorphisms and Clinicopathological Factors to Predict One-Year Survival of Advanced Epithelial Ovarian Cancer Patients

\section{Detection Of XRCC Gene Polymorphisms}

The polymorphic variants of XRCC1 and XRCC3 genes were detected by polymerase chain reaction-restriction fragment length polymorphism (PCR-RFLP) method. The genomic DNA was isolated from blood samples using a commercial kit (Wizard $^{\mathrm{TM}}$ Genomic DNA Purification Kit, Promega, Madison, WI, USA) or from paraffin sections if the patient has died at the beginning of the study (QIAamp DNA FFPE Tissue Kit, Qiagen, Germany).

PCR was performed in a reaction mixture of $25 \mu \mathrm{L}$ containing $2.5 \mu \mathrm{L}$ of $10 \mathrm{x}$ Thermopol buffer; $1.0 \mu \mathrm{L} \mathrm{10mM} \mathrm{dNTPs;} 0.5 \mu \mathrm{L}$ forward primer $(40 \mathrm{pmol} / \mu \mathrm{L}) ; 0.5$ $\mu \mathrm{L}$ reverse primer $(40 \mathrm{pmol} / \mu \mathrm{L}) ; 0.2 \mu \mathrm{L}$ Taq polymerase; $19.3 \mu \mathrm{L}$ ddH20 and $1.0 \mu \mathrm{L}$ DNA samples.

3. The Primers Used To Detect Four XRCC1 Polymorphic Variants Were:

a) XRCC1 Arg194Trp (CGG $\rightarrow$ TGG): 5'-GGTAAGCTGTACCTGTCACTC-3' and 5'-GACCCAGGAATCTGAGCC-3'

b) XRCC1 Arg280His (CGT $\rightarrow$ CAT): 5'-CCGTGGTGCTAACCTAATC-3' and 5'CACTCAGCACCACTACCACA-3'

c) XRCC1 Arg399Gln (CGG $\rightarrow$ CAG): 5'-TTGTGCTTTCTCTGTGTCCA-3' and 5'-TCCTCCAGCCTTTTCTGATA-3'

d) XRCC1 Arg399Gln* (CGG $\rightarrow$ CAG): 5'-CCCCAAGTACAGCCAGGTC-3' and 5'-TGTCCCGCTCCTCTCAGTAG-3'

The primers used for XRCC3 Thr241Met polymorphism was 5'GGTCGAGTGACAGTCCAAAC-3' and 5'-TGCAACGGCTGAGGGTCTT-3'.

The PCR conditions were: initial denaturation at $94^{\circ} \mathrm{C}$ for $5 \mathrm{~min}$, followed by 30 cycles at $94^{\circ} \mathrm{C}$ for $30 \mathrm{~s}$, at $60^{\circ} \mathrm{C}$ for $30 \mathrm{~s}$, at $72^{\circ} \mathrm{C}$ for $30 \mathrm{~s}$, and final extension at $72^{\circ} \mathrm{C}$ for $5 \mathrm{~min}$. The amplification products were visualized using agarose electrophoresis.

4. Statistical Analyses

Survival analyses were done using the Kaplan-Meier analysis and Cox proportional hazard assumption test. Death due to ovarian cancer was set as the failure event whereas the period between the last date of chemotherapy and the time of death or one-year later was defined as the survival time. Survival curve analyses were performed using the Kaplan-Meier estimation curves. A log-rank p of $<0.05$ was considered significant. The hazard ratio (HR) and its $95 \%$ confidence interval (CI) were calculated from selected predictors using the Cox regression model.

Scoring system was developed and tested using the receiver operating characteristic (ROC) curve analyses. Diagnostic performance of the prediction model was showed by the sensitivity, specificity, positive and negative likelihood ratios (LR+ and LR-), and the area under the ROC curve (AUC). The posttest probability was then calculated as $\mathrm{LR} /(\mathrm{LR}+1) \times 100 \%$ using the $\mathrm{LR}+$ value.

All statistical analyses were perfomed using the STATA version 10.0 software (STATA Corporation, Texas, USA). 
Chamim S. Singoprawiro, Iswari Setianingsih, Bambang Sutrisna, Nuryati C. Siregar, Andrijono

\section{Results and Discussion}

\section{Results}

There were 134 EOC patients during the study period; however 5 were excluded due to incomplete treatment, leaving a total of 129 cases for further analyses. Patients' median age was 49 (23-72) years old. Most patients came with stage III disease and serous carcinoma was the most common histopathology subtype (Table1).

Table 1

Characteristics of the study subjects $(n=129)$

\begin{tabular}{lcc}
\hline Characteristic & n & \% \\
\hline Age group & & \\
\hline$<50$ years & 65 & 50.4 \\
\hline$\geq 50$ years & 64 & 49.6 \\
\hline Diseas stage & 121 & \\
\hline Stage III & 8 & 63.8 \\
\hline Stage IV & 6.2 \\
\hline Histopathological subtype & \\
\hline Serous & 78 & 60.5 \\
\hline Mucinous & 19 & 14.7 \\
\hline Endometrioid & 12 & 9.3 \\
\hline Clear cell & 19 & 14.7 \\
\hline Tumor Brenner & 1 & 0.8 \\
\hline Histopathological grade & & \\
\hline$\quad$ High-risk & 106 & 82.2 \\
\hline Low-risk & 23 & 17.8 \\
\hline Residual disease & & \\
\hline$>1 \mathrm{~cm}$ & 114 & 88.4 \\
\hline
\end{tabular}

All patients were followed-up until one-year after treatment completion. There were $123(93.5 \%)$ patients who achieved complete response (CR); one patient $(0.8 \%)$ had partial response, whereas the rest 5 (3.9\%) patients had no response. Bivariate analysis found that residual tumor was significantly associated with one-year mortality (Table 2). In addition, the XRCC1 Arg300Gln polymorphism with Gln/Gln homozygous mutation showed a tendency for a higher risk compared to the normal allele Arg/Arg or Arg/Gln variant (Table 2). Kaplan-Meier survival analyses showed only residual tumor that significantly associated with 1-year mortality (Figure 1A-F). However, XRCC1 Arg399Gln polymorphism of Gln/Gln allel tended to have worse survival than Arg/Gln or Arg/Arg normal alelles. 
A Prognostic Model Based on XRCC1 Gene Polymorphisms and Clinicopathological Factors to Predict One-Year Survival of Advanced Epithelial Ovarian Cancer Patients

Table 2

Factors Associated with One-Year Survival of Advanced Stage Epithelial Ovarian Cancer Patients after Surgery and Chemotherapy

\begin{tabular}{|c|c|c|c|c|c|}
\hline Variable & $\begin{array}{c}\text { Died } \\
n=14\end{array}$ & $\begin{array}{c}\text { Alive } \\
\mathrm{n}=115\end{array}$ & $\mathbf{p}$ & HR & $95 \% \mathrm{CI}$ \\
\hline \multicolumn{6}{|l|}{ Disease stage } \\
\hline Stage III & $12(9.9 \%)$ & $109(90.1 \%)$ & & 1.0 & \\
\hline StageIV & $2(25.0 \%)$ & $6(75.0 \%)$ & 0.155 & 3.0 & $0.7-13.3$ \\
\hline \multicolumn{6}{|l|}{ Histopathology subtype } \\
\hline Serous & $7(9.0 \%)$ & $71(91.0 \%)$ & & 1.0 & \\
\hline Mucinous & $1(5.3 \%)$ & $18(94.7 \%)$ & 0.613 & 0.6 & $0.07-4.7$ \\
\hline Clear cell & $2(16.7 \%)$ & $10(83.3 \%)$ & 0.417 & 1.9 & $0.4-9.2$ \\
\hline Endometrioid+Brenner & $4(20.0 \%)$ & $16(80.0 \%)$ & 0.170 & 2.4 & $0.7-8.1$ \\
\hline \multicolumn{6}{|l|}{ Residual Disease } \\
\hline$<1 \mathrm{~cm}$ & $10(8.8 \%)$ & $104(91.2 \%)$ & \multirow[t]{2}{*}{0.039} & 1.0 & \\
\hline$>1 \mathrm{~cm}$ & $4(26.7 \%)$ & $11(73.3 \%)$ & & 3.4 & $1.1-10.9$ \\
\hline \multicolumn{6}{|l|}{ XRCC1 } \\
\hline \multicolumn{6}{|l|}{ Arg194Trp } \\
\hline Arg/Arg & $7(11.5 \%)$ & $54(88.5 \%)$ & & 1.0 & \\
\hline Arg/Trp & $6(11.3 \%)$ & $47(88.7 \%)$ & 0.981 & 1.0 & $0.3-2.9$ \\
\hline Trp/Trp & $1(6.7 \%)$ & $14(93.3 \%)$ & 0.588 & 0.6 & $0.07-4.6$ \\
\hline \multicolumn{6}{|l|}{ Arg280His } \\
\hline Arg/Arg & $10(10.3 \%)$ & $87(89.7 \%)$ & \multirow[t]{3}{*}{0.771} & 1.0 & \\
\hline Arg/His & $4(12.5 \%)$ & $28(87.5 \%)$ & & 1.2 & $0.4-3.8$ \\
\hline His/His & $0(0.0 \%)$ & $0(0.0 \%)$ & & - & - \\
\hline \multicolumn{6}{|l|}{ Arg399GIn } \\
\hline Arg/Arg & $5(9.8 \%)$ & $46(90.7 \%)$ & \multirow{3}{*}{$\begin{array}{l}0.773 \\
0.118 \\
\end{array}$} & 1.0 & \\
\hline Arg/Gln & $6(8.8 \%)$ & $62(91.2 \%)$ & & 0.8 & $0.3-2.8$ \\
\hline Gln/Gln & $3(30.0 \%)$ & $7(70.0 \%)$ & & 3.1 & $0.7-13.1$ \\
\hline \multicolumn{6}{|l|}{ XRCC3 } \\
\hline \multicolumn{6}{|l|}{ Thr241Met } \\
\hline Thr/Thr & $14(11.8 \%)$ & $105(88.2 \%)$ & \multirow{3}{*}{0.858} & 1.0 & \\
\hline Thr/Met & $0(0,0 \%)$ & $10(100.0 \%)$ & & - & \\
\hline Met/Met & $0(0,0 \%)$ & $0(0.0 \%)$ & & - & - \\
\hline
\end{tabular}

HR: hazard ratio; SE: standard error; CI: confidence interval 
Chamim S. Singoprawiro, Iswari Setianingsih, Bambang Sutrisna, Nuryati C. Siregar, Andrijono

A. Histopathology subtype

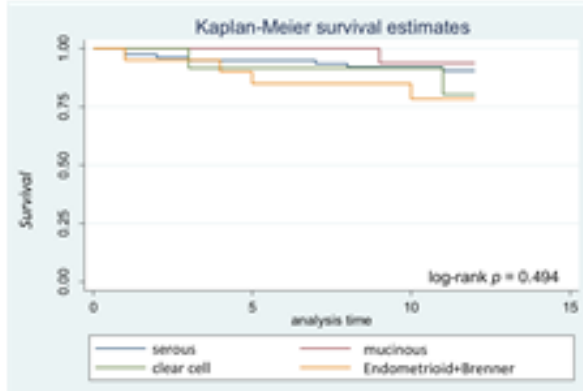

C. XRCC1 Arg194Trp polymorphism

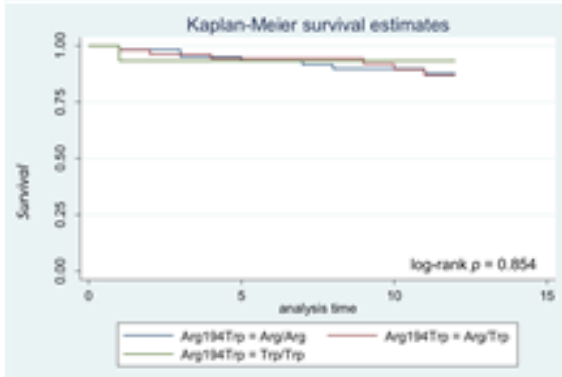

E. XRCC1 Arg399 Gln polymorphism

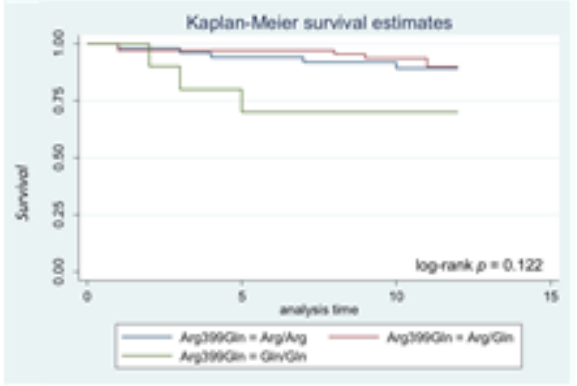

B. Residual disease

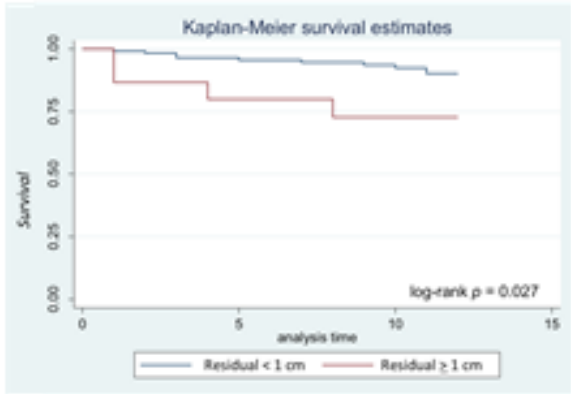

D. XRCC1 Arg280His polymorphism

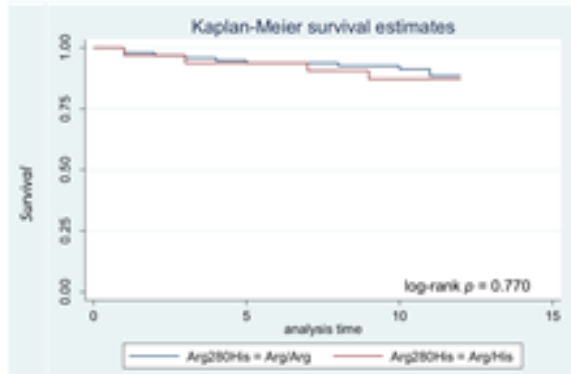

F. XRCC3 Thr241Met polymorphism

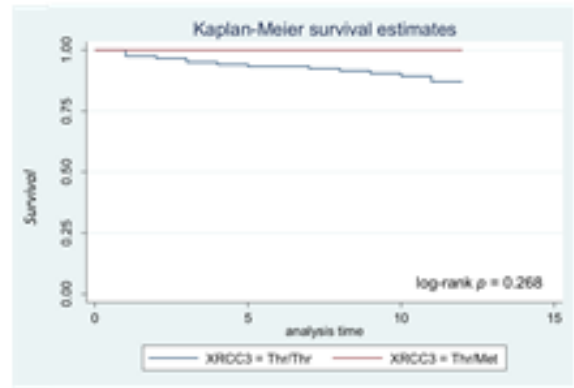

Figure 1

A-F. Kaplan-Meier analyses for 1-year survival of advanced EOC patients after therapy

Multivariate analyses confirmed residual tumor as an independent risk factor for one-year mortality (Table 3). However, in the final calculation model, histological subtype and XRCC1 gene polymorphisms were included. The scoring equation was as follows: 
A Prognostic Model Based on XRCC1 Gene Polymorphisms and Clinicopathological Factors to Predict One-Year Survival of Advanced Epithelial Ovarian Cancer Patients

Table 3

Final Model to Predict One-Year Mortality in Patients with Advanced Stage Epithelial Ovarian Cancer After Surgery and Chemotherapy

\begin{tabular}{lcccccc}
\hline Variable & HR & SE & Z & 95\% CI & p \\
\hline Histopathology & & & & & & \\
\hline Mucinous & 0.5 & 0.5 & -0.68 & 0.1 & 4.0 & 0.496 \\
\hline Clear Cell & 1.6 & 1.3 & 0.56 & 0.3 & 8.3 & 0.575 \\
\hline Endometrioid+Brenner & 3.2 & 2.2 & 1.73 & 0.9 & 12.0 & 0.084 \\
\hline Residual tumor $>1 \mathrm{~cm}$ & 3.7 & 2.3 & 2.06 & 1.1 & 12.8 & $\mathbf{0 . 0 3 9}$ \\
$\begin{array}{l}\text { XRCC1 Arg399Gln } \\
\text { polymorphism }\end{array}$ & & & & & & \\
\hline$\quad$ Arg/Gln & 1.0 & 0.6 & -0.05 & 0.3 & 3.4 & 0.959 \\
\hline Gln/Gln & 4.3 & 3.3 & 1.90 & 1.0 & 19.4 & $\mathbf{0 . 0 5 7}$ \\
\hline
\end{tabular}

HR: hazard ratio; SE: standard error; CI: confidence interval

\section{Score to predict mortality $=-3,3 M+2,7 C C+8,4 E B+10 R-0,2 A r g G l n+9,2 G l n G l n$}

With M: mucinous subtype; CC: clear cell subtype; endometriod or Brenner subtype; R: residual tumo; ArgGln: XRCC1 Arg399Gln polymorphism allel Arg/Gln; and GlnGln: XRCC1 Arg399/Gln polymorphism allel Gln/Gln.

Using the ROC curve analysis, a cutoff point of mortality prediction scoring was selected at the value off 9.2. Patients who had scores $>9.2$ were at risk of died at 1-year after treatmet. This prediction model showed $50.0 \%$ sensivity, $89.6 \%$ specificity, accuracy of $85.3 \%$, LR+ of 4.7, LR- of 0.6 and an AUC of $69.8 \%$ (Figure 2 ). The posttest probability of the prediction model was $82.7 \%$ meaning that the predictor score of $>9.2$ is a good diagnostic test to predict mortality of advanced EOC patients after surgery and chemotherapy.

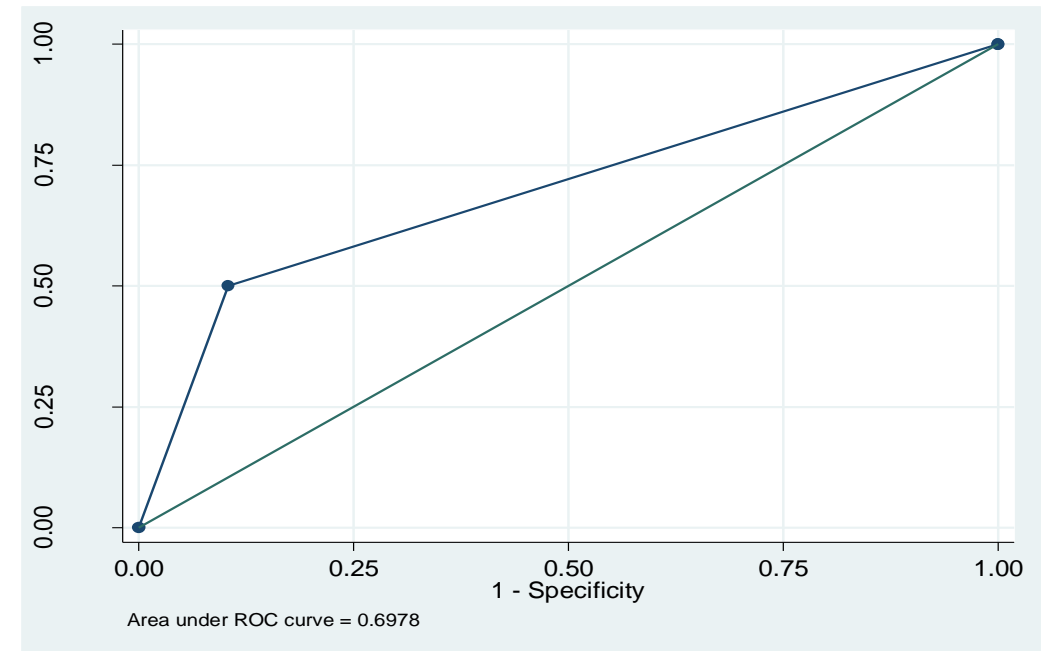

Figure 2

The ROC curve of 1-year mortality prediction scores of advanced EOC patients after therapy 
Chamim S. Singoprawiro, Iswari Setianingsih, Bambang Sutrisna, Nuryati C. Siregar, Andrijono

\section{Discussion}

This study is the first in Indonesia to report XRCC1 gene polymorphism as a surrogate marker of clinical outcome of advanced EOC patients after adjuvant chemotherapy. The XRCC1 gene polymorphisms are frequently occurs with the Arg/Gln allele variants are the most common form (52.7\%), followed by Arg/Trp (41.1\%) and $\mathrm{Arg} / \mathrm{His}$ variants $(24.8 \%)$. These three polymorphisms are the most studied SNPs (Hung, Hall, Brennan, \& Boffetta, 2005). These frequencies of gene polymorphisms were higher than the previous report which found that heterozygous XRCC1 Arg/Gln polymorphism was $42.4 \%$; while $\mathrm{Arg} / \mathrm{Trp}$ was $21.4 \%$ and $\mathrm{Arg} / \mathrm{His}$ was $16.7 \%$ (Miao et al., 2012).

Our study did not found strong association between XRCC gene polymorphism and 1-year mortality. However, the XRCC1 Gln399Gln homozygous polymorphism showed a tendency for worse prognosis compare to the other variant, Arg/Gln. Lower survival rates were also shown previously in China among EOC patients with Gln/Gln variant of XRCC1 Arg399Gln polymorphism (Cheng et al., 2012).

A case-control study in Serbia found XRCC1 Arg399Gln polymorphism in $32 \%$ of ovarian cancer cases, significantly higher than the control group (26.9\%) (Malisic, Krivokuca, Boljevic, \& Jankovic, 2015). However, it is not known how a single amino acid substitution at codon 399 can affect clinical outcome of the EOC patients. The logical explanation of this finding could be an increased of DNA repair capacity since XRCC1 protein is involved in DNA single-strand break repair and base-excision repair. Another difference of our study results was the observation time; our study subjects were followed-up for one year, while the study in China followed the patients for three years.

Resistance to platinum-based chemotherapy could be caused by successful DNA repair. The XRCC1 protein is a key molecule during DNA repair after chemotherapy. An immunohistochemical study showed that the expression of XRCC1 protein was associated with worse clinicopathology and prognosis; there was an increased risk of mortality $(p<0.001)$ and progression $(p<0.001)$ when compared to the negative XRCC1 protein (Abdel-Fatah et al., 2013). Further analyses showed that XRCC1 protein expression could be an independent predictor for survival and progression-free survival after controlling other variables, i.e. CA125 level, disease stage, histopathology type, residual tumor, surgery and chemotherapy (Abdel-Fatah et al., 2013).

The XRCC1 gene product has a complex association with other three DNA repair enzymes in the BER pathway, i.e. ligase 3 DNA, polymerase DNA and poly (ADP-ribosa) PARP polimerase. Polymorphism of Arg399Gln is located in exon 19 which is an important binding site of PARP-1. The PARP-1 molecule quickly bind to the SSB site and activate DNA repair pathway causing repair protein accumulation at the damage site (Seibold et al., 2015). It is not known whether or not this accumulation of repair proteins results in increased repair capacity. 
A Prognostic Model Based on XRCC1 Gene Polymorphisms and Clinicopathological Factors to Predict One-Year Survival of Advanced Epithelial Ovarian Cancer Patients

The XRCC3 gene polymorphism was only found in a small number of patients in this study. As comparison, previous study in China found Thr/Met allele in $43.7 \%$ while homozygous mutation of Met/Met was found in $11.2 \%$ of 310 ovarian cancer patients (Cheng et al., 2012). Our study cannot confirm the role of XRCC3 gene polymorphism on the survival of EOC patients after chemotherapy. The XRCC3 protein is one of the Rad51-related proteins, which play roles in the double-strand breaks repair to maintain genomic integrity during homologous recombination process (Brenneman, Weiss, Nickoloff, \& Chen, 2000). Polymorphism in the XRCC3 gene may reduce DNA repair capacity (Matullo et al., 2001). This could be the reason why the XRCC3 gene polymorphism was not associated with mortality; tumor cells, which did not undergo a successful DNA repair after chemotherapy will eventually die.

In the final model to predict mortality, the XRCC1 gene polymorphism was included as well as histopathology subtype and residual tumor. Histopathology subtype, especially clear cell, mucinous, and endometrioid tumors is important factor associated with survival. Although not included in the final model, tumor stage is still an important prognostic factor for overall survival and disease-free survival (Zanetta et al., 1998). Other clinical factors that has been known to have prognostic role were age, performance status, tumor stage, histopathology grade and residual tumor (Omura et al., 1991). Residual tumor is a major prognostic factor. In the era of platinum-based chemotherapy, maximum cytoreduction is an important factor for survival in advanced stage EOC patients (Bristow, Tomacruz, Armstrong, Trimble, \& Montz, 2002). Therefore, complete cytoreduction should be the ultimate goal. If it is not achievable, the goal of surgery should be optimal reduction (residual tumor < $1 \mathrm{~cm})$ (Elattar, Bryant, Winter-Roach, Hatem, \& Naik, 2011).

\section{Conclusions}

Prognosis of advanced stage EOC patients can be predicted by a prediction model consisting histopathology subtype, residual tumor and XRCC1 gene polymorphisms. This prediction model showed a good accuracy and posttest probability test result. Validation study is needed to confirm these findings in larger samples. 
Chamim S. Singoprawiro, Iswari Setianingsih, Bambang Sutrisna, Nuryati C. Siregar, Andrijono

\section{BIBLIOGRAPHY}

Abdel-Fatah, Tarek, Sultana, Rebeka, Abbotts, Rachel, Hawkes, Claire, Seedhouse, Claire, Chan, Stephen, \& Madhusudan, Srinivasan. (2013). Clinicopathological and functional significance of XRCC1 expression in ovarian cancer. International Journal of Cancer, 132(12), 2778-2786. Google Scholar

Almeida, Gabriela M., Duarte, Tiago L., Farmer, Peter B., Steward, William P., \& Jones, George D. D. (2008). Multiple end-point analysis reveals cisplatin damage tolerance to be a chemoresistance mechanism in a NSCLC model: Implications for predictive testing. International Journal of Cancer, 122(8), 1810-1819. Google Scholar

Aziz, M. F. (2009). Gynecological cancer in Indonesia. J Gynecol Oncol, 20, 8-10. Google Scholar

Berek, Jonathan S., \& Hacker, Neville F. (2010). Berek and Hacker's gynecologic oncology. Lippincott Williams \& Wilkins. Google Scholar

Bewick, Mary A., Conlon, Michael S. C., \& Lafrenie, Robert M. (2006). Polymorphisms in XRCC1, XRCC3, and CCND1 and survival after treatment for metastatic breast cancer. Journal of Clinical Oncology, 24(36), 5645-5651. Google Scholar

Brenneman, Mark A., Weiss, Anne E., Nickoloff, Jac A., \& Chen, David J. (2000). XRCC3 is required for efficient repair of chromosome breaks by homologous recombination. Mutation Research/DNA Repair, 459(2), 89-97. Google Scholar

Bristow, Robert E., Tomacruz, Rafael S., Armstrong, Deborah K., Trimble, Edward L., \& Montz, F. J. (2002). Survival effect of maximal cytoreductive surgery for advanced ovarian carcinoma during the platinum era: a meta-analysis. In Database of Abstracts of Reviews of Effects (DARE): Quality-assessed Reviews [Internet]. Centre for Reviews and Dissemination (UK). Google Scholar

Cheng, Chun Xia, Xue, Min, Li, Kai, \& Li, Wu Sheng. (2012). Predictive value of XRCC1 and XRCC3 gene polymorphisms for risk of ovarian cancer death after chemotherapy. Asian Pacific Journal of Cancer Prevention, 13(6), 2541-2545. Google Scholar

Elattar, Ahmed, Bryant, Andrew, Winter-Roach, Brett A., Hatem, Mohamed, \& Naik, Raj. (2011). Optimal primary surgical treatment for advanced epithelial ovarian cancer. Cochrane Database of Systematic Reviews, (8). Google Scholar

Goode, Ellen L., Ulrich, Cornelia M., \& Potter, John D. (2002). Polymorphisms in DNA repair genes and associations with cancer risk. Cancer Epidemiology and Prevention Biomarkers, 11(12), 1513-1530. Google Scholar

Hung, Rayjean J., Hall, Janet, Brennan, Paul, \& Boffetta, Paolo. (2005). Genetic 
A Prognostic Model Based on XRCC1 Gene Polymorphisms and Clinicopathological Factors to Predict One-Year Survival of Advanced Epithelial Ovarian Cancer Patients

polymorphisms in the base excision repair pathway and cancer risk: a HuGE review. American Journal of Epidemiology, 162(10), 925-942. Google Scholar

Jhamb, Namita, \& Lambrou, Nicholas C. (2010). Epidemiology and clinical presentation of ovarian cancer. Early Diagnosis and Treatment of Cancer Series: Ovarian Cancer, Yang SC (Ed), Saunders Elsevier, Philadelphia, 1. Google Scholar

Jinawath, Natini, \& Shih, I. (2010). Biology and pathology of ovarian cancer. Early Diagnosis and Treatment of Cancer. Ovarian Cancer, 17-32. Google Scholar

Malisic, Emina J., Krivokuca, Ana M., Boljevic, Ivana Z., \& Jankovic, Radmila N. (2015). Impact of RAD51 G135C and XRCC1 Arg399Gln polymorphisms on ovarian carcinoma risk in Serbian women. Cancer Biomarkers, 15(5), 685-691. Google Scholar

Matullo, Giuseppe, Palli, Domenico, Peluso, Marco, Guarrera, Simonetta, Carturan, Sonia, Celentano, Egidio, Krogh, Vittorio, Munnia, Armelle, Tumino, Rosario, \& Polidoro, Silvia. (2001). XRCC1, XRCC3, XPD gene polymorphisms, smoking and 32 P-DNA adducts in a sample of healthy subjects. Carcinogenesis, 22(9), 1437-1445. Google Scholar

Miao, Jin, Zhang, Xian, Tang, Qiong Lan, Wang, Xiao Yu, \& Kai, Li. (2012). Prediction value of XRCC 1 gene polymorphism on the survival of ovarian cancer treated by adjuvant chemotherapy. Asian Pacific Journal of Cancer Prevention, 13(10), 5007-5010. Google Scholar

Novak, Emil. (2007). Berek \& Novak's gynecology. Lippincott Williams \& Wilkins. Google Scholar

Omura, George A., Brady, M. F., Homesley, H. D., Yordan, E., Major, F. J., Buchsbaum, H. J., \& Park, R. C. (1991). Long-term follow-up and prognostic factor analysis in advanced ovarian carcinoma: the Gynecologic Oncology Group experience. Journal of Clinical Oncology, 9(7), 1138-1150. Google Scholar

Seibold, Petra, Schmezer, Peter, Behrens, Sabine, Michailidou, Kyriaki, Bolla, Manjeet K., Wang, Qin, Flesch-Janys, Dieter, Nevanlinna, Heli, Fagerholm, Rainer, \& Aittomäki, Kristiina. (2015). A polymorphism in the base excision repair gene PARP2 is associated with differential prognosis by chemotherapy among postmenopausal breast cancer patients. BMC Cancer, 15(1), 1-11. Google Scholar

Shen, M. Richard, Jones, Irene M., \& Mohrenweiser, Harvey. (1998). Nonconservative amino acid substitution variants exist at polymorphic frequency in DNA repair genes in healthy humans. Cancer Research, 58(4), 604-608. Google Scholar

Winarto, Hariyono, Laihad, Bismarck Joel, \& Nuranna, Laila. (2014). Modification of cutoff values for HE4, CA125, the risk of malignancy index, and the risk of malignancy algorithm for ovarian cancer detection in Jakarta, Indonesia. Asian Pacific Journal of Cancer Prevention, 15(5), 1949-1953. Google Scholar 
Chamim S. Singoprawiro, Iswari Setianingsih, Bambang Sutrisna, Nuryati C. Siregar, Andrijono

Zanetta, G., Rota, S., Chiari, S., Bonazzi, C., Bratina, G., Torri, V., \& Mangioni, C. (1998). The accuracy of staging: an important prognostic determinator in stage I ovarian carcinoma: a multivariate analysis. Annals of Oncology, 9(10), 10971101. Google Scholar

Zhao, Yi, Deng, Xin, Wang, Zhen, Wang, Qiang, \& Liu, Yixia. (2012). Genetic polymorphisms of DNA repair genes XRCC1 and XRCC3 and risk of colorectal cancer in Chinese population. Asian Pacific Journal of Cancer Prevention, 13(2), 665-669. Google Scholar

\section{Copyright holder:}

Chamim S. Singoprawiro, Iswari Setianingsih, Bambang Sutrisna, Nuryati C. Siregar, Andrijono (2022)

First publication right:

Syntax Literate: Jurnal Ilmiah Indonesia

This article is licensed under:

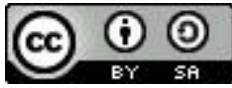

